Medical Research, The Australian National University, Canberra, ACT, Australia; ${ }^{3}$ Cancer Research Division, Peter MacCallum Cancer Centre, Melbourne, Vic, Australia; ${ }^{4}$ Sir Peter MacCallum Department of Oncology, University of Melbourne, Melbourne, Vic, Australia; ${ }^{5}$ Department of Pathology, Peter MacCallum Cancer Centre, Parkville, Vic, Australia; ${ }^{6}$ Department of Medical Oncology, Peter MacCallum Cancer Centre, Melbourne, Vic, Australia; ${ }^{7}$ Personalised Oncology Division, The Walter and Eliza Hall Institute of Medical Research, Parkville, Vic, Australia

Contact Dr Michael Christie.

E-mail: Michael.Christie@mh.org.au

1. Roberts CW, Leroux MM, Fleming MD, et al. Highly penetrant, rapid tumorigenesis through conditional inversion of the tumor suppressor gene Snf5. Cancer Cell 2002; 2: 415-25.

2. Parker NA, Al-Obaidi A, Deutsch JM. SMARCB1/INI1-deficient tumors of adulthood. F1000Res 2020; 9: 662.

3. Agaimy A, Hartmann A, Antonescu CR, et al. SMARCB1 (INI-1)deficient sinonasal carcinoma: a series of 39 cases expanding the morphologic and clinicopathologic spectrum of a recently described entity. Am J Surg Pathol 2017; 41: 458-71.

4. Perry A, Fuller CE, Judkins AR, et al. INI1 expression is retained in composite rhabdoid tumors, including rhabdoid meningiomas. Mod Pathol 2005; 18: 951-8

5. Centore RC, Sandoval GJ, Soares LMM, et al. Mammalian SWI/SNF chromatin remodeling complexes: emerging mechanisms and therapeutic strategies. Trends Genet 2020; 36: 936-50.

6. Sesboue C, Le Loarer F. SWI/SNF-deficient thoraco-pulmonary neoplasms. Semin Diagn Pathol 2021; 38: 183-94.

7. Yoshida K, Fujiwara Y, Goto Y, et al. The first case of SMARCB (INI1) - deficient squamous cell carcinoma of the pleura: a case report. BMC Cancer 2018; 18: 398.

8. The AACR Project GENIE Consortium. AACR Project GENIE: powering precision medicine through an international consortium. Cancer Discov 2017: 7: 818-31.

9. Cerami E, Gao J, Dogrusoz U, et al. The cBio cancer genomics portal an open platform for exploring multidimensional cancer genomics data. Cancer Discov 2012; 2: 401-4.

10. Gao J, Aksoy BA, Dogrusoz U, et al. Integrative analysis of complex cancer genomics and clinical profiles using the cBioPortal. Sci Signal 2013; 6: 11.

11. Mittal P, Roberts CWM. The SWI/SNF complex in cancer - biology, biomarkers and therapy. Nat Rev Clin Oncol 2020; 17: 435-48.

12. Leruste A, Tosello J, Ramos RN, et al. Clonally expanded T cells reveal immunogenicity of rhabdoid tumors. Cancer Cell 2019; 36: 597-612.

DOI: https://doi.org/10.1016/j.pathol.2021.11.010

\section{A case of steroid responsive nivolumab induced cholangitis}

To the Editor,

Immune checkpoint inhibitors (ICIs) are increasingly being used for the treatment of a range of advanced malignancies after demonstrating sustained clinical responses and improved long term survival in phase III clinical trials for a subset of treated patients. ${ }^{1}$ The current ICIs in clinical use are monoclonal antibodies that bind specific immune checkpoint proteins: cytotoxic T-lymphocyte-associated protein 4 (CTLA-4); programmed cell death protein 1 (PD-1) or its ligand (PD-L1). Upon binding, these antibodies inhibit the action of these checkpoints and enhance the T-cell mediated anti-tumour response. ${ }^{2}$ This increased immune response is also associated with a distinct set of immunologically mediated toxicities referred to as immune related adverse events
(irAEs). Hepatotoxicity is a common irAE which typically manifests as an asymptomatic rise in the transaminases. Small and large duct cholangitis have been very rarely reported and currently lack established diagnostic criteria or specific treatment guidelines. ${ }^{4}$ Nivolumab is a PD-1 inhibitor currently approved in Australia for the treatment of non-small cell lung cancer (NSCLC) and other advanced cancers. ${ }^{5}$ Here we present the clinicopathological aspects of what is to our knowledge the first Australian case of nivolumab induced small duct cholangitis in a patient with NCSLC.

A 75-year-old female with locally advanced NSCLC was commenced on palliative nivolumab (480 mg, 4-weekly) after she presented with clinical and radiological disease progression despite initial treatment with chemoradiation. Her liver function tests (LFTs) were all within the normal range prior to starting nivolumab. Other past medical history included chronic obstructive pulmonary disease, previous embolic cerebrovascular accident secondary to chronic atrial fibrillation, and colonic adenocarcinoma currently in remission after resection and adjuvant chemotherapy. Her only medications at the time were apixaban $(2.5 \mathrm{mg}$ twice daily) and sotalol (40 mg twice daily). Routine blood tests 45 days after commencing nivolumab ( 2 cycles) demonstrated a cholestatic predominant LFT derangement with no synthetic dysfunction (Fig. 1). Tests for viral and autoimmune hepatitis were negative. Abdominal ultrasonography showed no biliary obstruction or liver metastases. Due to the temporal relationship with nivolumab administration the patient was treated for a presumptive immune related liver injury. Nivolumab was ceased and she was started on intravenous methylprednisolone followed by oral prednisone weaned over the subsequent two months leading to complete resolution of LFT derangement. She remained asymptomatic throughout this period. However, 15 days after her cessation of oral prednisone, the patient re-presented with nausea, jaundice and a rebound of her cholestatic LFT derangement. Further investigations with computed tomography of the abdomen and pelvis and magnetic resonance cholangiopancreatography were unremarkable. Additionally, a percutaneous liver biopsy was performed. The patient was again treated with 3 days of methylprednisolone followed by oral prednisone which was weaned and ceased 2 months later after resolution of her LFT derangement.

In view of the strong temporal correlation between drug administration and rise in LFTs, the normal radiological findings, the absence of other possible aetiologies and the histological findings outlined below, a diagnosis of small duct nivolumab induced cholangitis was made. It was subsequently decided to permanently discontinue her nivolumab. At time of writing, 15 months after the last administration of nivolumab, the patient has normal LFTs and stable disease despite having no further anti-cancer therapy.

Histopathology demonstrated expanded, mildly oedematous portal tract regions in which there was a mixed inflammatory cell infiltrate including neutrophils with smaller numbers of lymphocytes, eosinophils and histiocytes noted. Plasma cells were inconspicuous, and no interface hepatitis was seen. Interlobular bile ducts were damaged and focally disrupted with intraepithelial lymphocytes noted and cytokeratin 7 immunohistochemistry highlighted a mild ductular reaction. No periductal fibrosis was seen. Routine liver special stains were unremarkable and there was no significant fibrosis identified. As large duct obstruction and sepsis had 


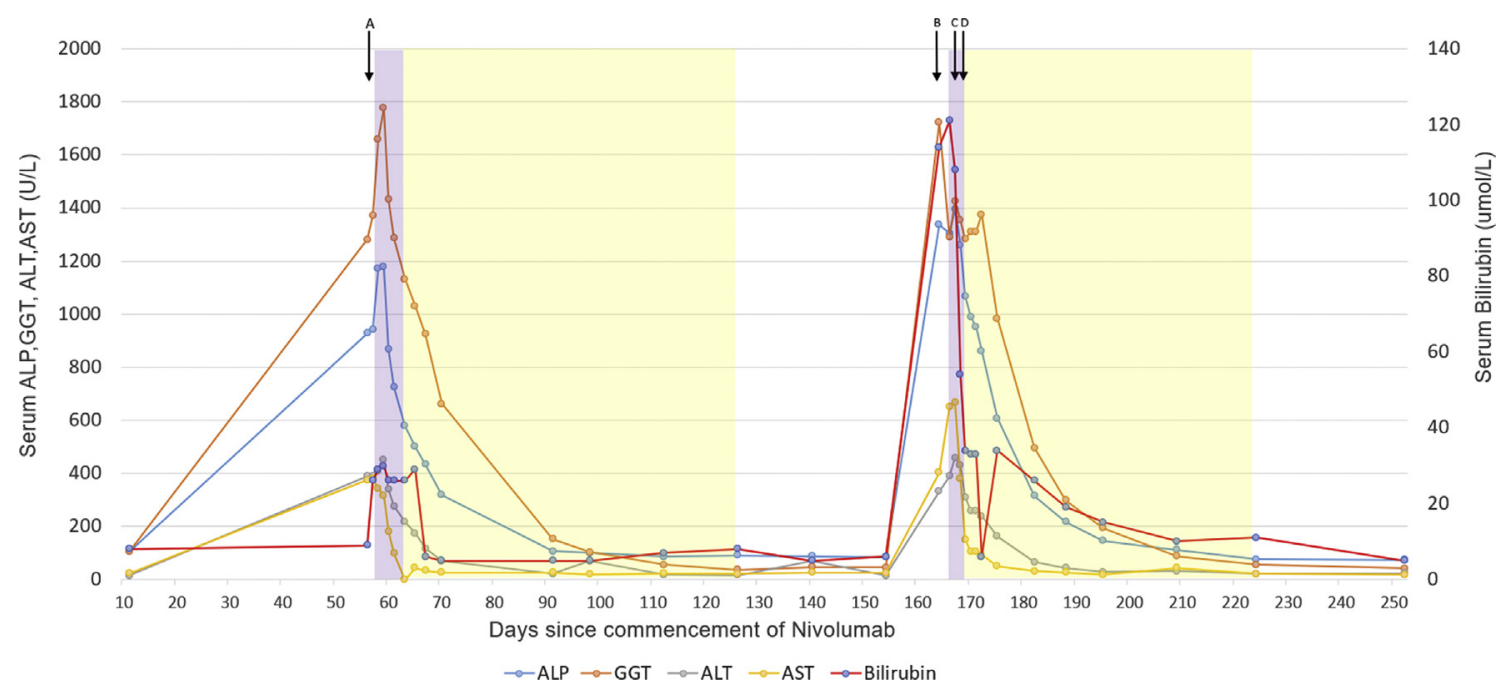

Fig. 1 Summary of timeline between nivolumab therapy, liver biochemistry, imaging, liver biopsy and corticosteroid therapy. The coloured regions depict periods of steroid therapy (purple, methylprednisone; yellow, oral prednisone). Black arrows represent the timing of investigations performed as follows: (A) liver ultrasonography; (B) computed tomography of the abdomen and pelvis; (C) magnetic resonance cholangiopancreatography; (D) liver biopsy. ALP, alkaline phosphatase; ALT, alanine transaminase; AST, aspartate transaminase; GGT, gamma-glutamyl transferase.

been excluded in this patient, this pattern of injury was consistent with a diagnosis of nivolumab induced cholangitis. Representative images are presented in Fig. 2.

ICI induced cholangitis is a rare but important potential irAE due to the increasing use and number of indications for ICIs. Since it was first described in $2017^{6}$ there have been 20 cases of biopsy-proven nivolumab associated cholangitis reported in the literature to date ${ }^{4,7-10}$ (Table 1). The collective experience of these clinicopathological reports are important due to the current lack of diagnostic criteria or evidence based therapeutic guidelines. ${ }^{6}$ Typically, cholestatic pattern ICI-related irAEs are more common with the use of PD-1 and PD-L1 inhibitors (such as nivolumab) rather than anti-CTLA-4 inhibitors, an effect which has been conjectured to be due to the differential expression of these molecules by biliary epithelial cells. ${ }^{11}$

Histological findings of ICI-cholangitis include lymphocytic bile duct infiltration with variable degrees of periductal fibrosis with intraepithelial lymphocytes and a CD8 $+\mathrm{T}$ cell predominance, a general feature of all ICI-irAEs. ${ }^{4}$ Overall, the response rate of ICI-cholangitis to steroid therapy has been reported to be poor in contrast to other types of immune related hepatobiliary disease. ${ }^{9,12}$ In their review, Onoyama and colleagues ${ }^{4}$ made a distinction between intra-hepatic, extra-hepatic and diffuse phenotypes of PD-1 inhibitor cholangitis noting that the two reported cases of purely intrahepatic disease both responded well to steroid therapy as was seen in our case. This raises the possibility that intrahepatic ICI-cholangitis may be more steroid responsive; however, there are currently limited data available to support this.

Another interesting feature of our case was that despite receiving an adequate steroid weaning duration as suggested by international guidelines for ICI hepatotoxicity, the patient still developed a rebound of disease following cessation of oral prednisone. The second disease flare which was more severe with hyperbilirubinaemia also responded well to corticosteroids. Currently there is no evidence to guide the optimal duration of therapy in such situations and thus it is unclear whether a longer oral prednisone wean would have been helpful. However, it does highlight the need for ongoing LFTs monitoring after apparent resolution of derangements and cessation of therapy for ICI-hepatotoxicity.

In conclusion, we present to our knowledge the first Australian case of biopsy demonstrated nivolumab related small duct cholangitis showing an excellent response to corticosteroid therapy for both the initial flare and subsequent rebound. Given previous reports of poor corticosteroid response, more clinicopathological data is needed to characterise the heterogeneous nature of ICI-cholangitis. Though rare, the increasingly common use of these agents makes this an important reaction pattern which pathologists and clinicians should be aware of.

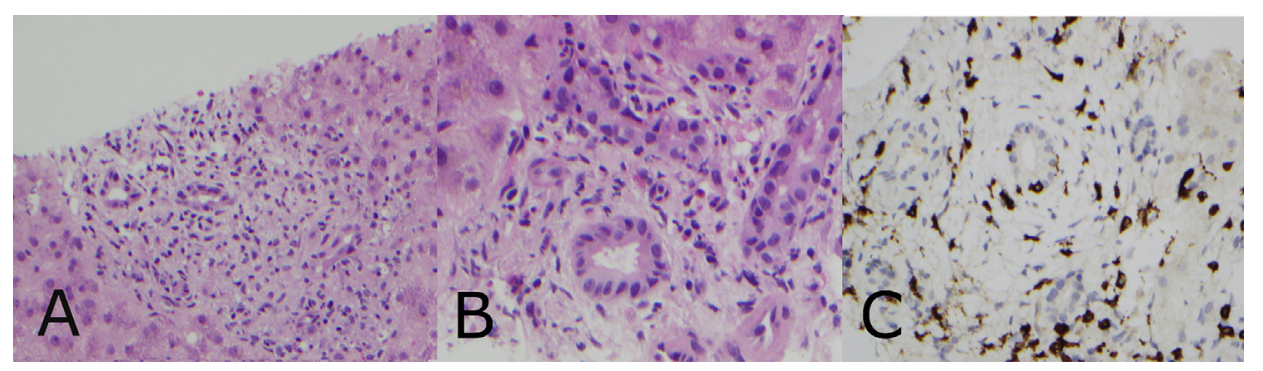

Fig. 2 Liver biopsy. (A) H\&E showing an oedematous portal tract region with duct damage visible. Note is made of adjacent hepatocytes showing two toned change. (B) Higher power H\&E showing duct damage with intra epithelial lymphocytes. (C) CD8 IHC shows predominance of CD8 positive T lymphocytes. 
Table 1 Summary of the clinical features of all previous cases of liver biopsy nivolumab associated cholangitis to our knowledge reported in the literature as of August 2021

\begin{tabular}{|c|c|c|c|c|c|c|}
\hline Original article ${ }^{a}$ & $\begin{array}{l}\text { Age and } \\
\text { gender }\end{array}$ & $\begin{array}{l}\text { Indication for } \\
\text { nivolumab therapy }\end{array}$ & Presentation & $\begin{array}{l}\text { Imaging modalities and } \\
\text { findings }\end{array}$ & Treatment & $\begin{array}{l}\text { Outcome of } \\
\text { hepatotoxicity }\end{array}$ \\
\hline Gelsomino (2017) & $79 \mathrm{M}$ & NSCLC & Itching, jaundice & $\begin{array}{l}\text { No abnormality on } \\
\text { imaging (not specified } \\
\text { which types performed) }\end{array}$ & $\begin{array}{l}\text { Methylprednisolone, } \\
\text { ursodeoxycholic acid }\end{array}$ & Partially resolved \\
\hline Kawakami (2017) & $64 \mathrm{M}$ & $\begin{array}{l}\text { NSCLC } \\
\quad \text { (adenocarcinoma) }\end{array}$ & $\begin{array}{l}\text { Fever, abdominal } \\
\text { discomfort }\end{array}$ & $\begin{array}{l}\text { CT: extrahepatic bile duct } \\
\text { dilation, hypertrophy of } \\
\text { the gallbladder } \\
\text { EUS: diffuse hypertrophy } \\
\text { of the gallbladder and } \\
\text { extrahepatic bile duct, } \\
\text { normal intrahepatic bile } \\
\text { duct findings }\end{array}$ & Prednisone & Not resolved \\
\hline Kawakami (2017) & $82 \mathrm{~F}$ & $\begin{array}{l}\text { NSCLC (squamous } \\
\text { cell carcinoma) }\end{array}$ & Fever, fatigue & $\begin{array}{l}\text { CT: extrahepatic bile duct } \\
\text { dilation } \\
\text { EUS: diffuse hypertrophy } \\
\text { of the extrahepatic bile } \\
\text { duct }\end{array}$ & Biliary drainage & Unknown \\
\hline Kashima (2017) & $63 \mathrm{M}$ & $\begin{array}{l}\text { NSCLC } \\
\quad \text { (adenocarcinoma) }\end{array}$ & $\begin{array}{l}\text { Epigastric pain, } \\
\text { soft stools }\end{array}$ & $\begin{array}{l}\text { CT: wall thickening at the } \\
\text { lower part of the bile } \\
\text { duct and cholecystitis }\end{array}$ & $\begin{array}{l}\text { Prednisone and biliary } \\
\text { drainage, moderate } \\
\text { response }\end{array}$ & Partially resolved \\
\hline Doherty (2017) & $59 \mathrm{~F}$ & $\begin{array}{l}\text { Melanoma (BRAF } \\
\text { wild-type) }\end{array}$ & Abnormal LFTs & No imaging reported & $\begin{array}{l}\text { Prednisone and } \\
\text { ursodeoxycholic acid }\end{array}$ & $\begin{array}{l}\text { Completely } \\
\text { resolved }\end{array}$ \\
\hline Hamoir (2018) & $71 \mathrm{M}$ & NSCLC & Abnormal LFTs & $\begin{array}{l}\text { CT: normal } \\
\text { MRCP: intrahepatic } \\
\text { cholangitis }\end{array}$ & $\begin{array}{l}\text { Methylprednisolone and } \\
\text { ursodeoxycholic acid }\end{array}$ & $\begin{array}{l}\text { Completely } \\
\text { resolved }\end{array}$ \\
\hline Kuraoka (2018) & $69 \mathrm{M}$ & $\begin{array}{l}\text { NSCLC } \\
\quad \text { (adenocarcinoma) }\end{array}$ & $\begin{array}{l}\text { Pruritic rash, } \\
\text { abnormal LFTs }\end{array}$ & $\begin{array}{l}\text { CT: diffuse hypertrophy of } \\
\text { extrahepatic bile ducts } \\
\text { EUS: slight dilation of the } \\
\text { extrahepatic bile ducts }\end{array}$ & $\begin{array}{l}\text { Prednisone and } \\
\text { methylprednisolone }\end{array}$ & $\begin{array}{l}\text { No resolution, } \\
\text { patient death }\end{array}$ \\
\hline Sawada (2019) & $76 \mathrm{M}$ & $\begin{array}{l}\text { Gastric cancer (tubular } \\
\text { adenocarcinoma) }\end{array}$ & Abnormal LFTs & $\begin{array}{l}\text { CT: mild dilation of the } \\
\text { extrahepatic bile duct }\end{array}$ & $\begin{array}{l}\text { Prednisone and } \\
\text { ursodeoxycholic acid }\end{array}$ & $\begin{array}{l}\text { Completely } \\
\text { resolved }\end{array}$ \\
\hline Oda (2019) & $43 \mathrm{M}$ & $\begin{array}{l}\text { Gastric cancer } \\
\quad(\text { adenocarcinoma })\end{array}$ & $\begin{array}{l}\text { Fever, tachycardia, } \\
\text { appetite loss, } \\
\text { malaise }\end{array}$ & $\begin{array}{l}\text { CT: no abnormality } \\
\text { detected }\end{array}$ & $\begin{array}{l}\text { Prednisone and } \\
\text { mycophenolate mofetil }\end{array}$ & $\begin{array}{l}\text { No resolution, } \\
\text { patient death }\end{array}$ \\
\hline Calugreanu (2019) & $43 \mathrm{~F}$ & Melanoma & $\begin{array}{l}\text { Epigastric pain, } \\
\text { anorexia }\end{array}$ & $\begin{array}{l}\text { CT: multiple strictures and } \\
\text { dilation }\end{array}$ & Prednisone & Partially resolved \\
\hline Onoyama (2020) & $82 \mathrm{~F}$ & NSCLC & Abnormal LFTs & $\begin{array}{l}\text { Biliary dilation, diffuse } \\
\text { hypertrophy of the tract }\end{array}$ & Methylprednisolone & Partially resolved \\
\hline McClure (2020) & $79 \mathrm{M}$ & $\begin{array}{l}\text { NSCLC } \\
\quad \text { (adenocarcinoma) }\end{array}$ & $\begin{array}{l}\text { LFT derangement, } \\
\text { abdominal pain }\end{array}$ & $\begin{array}{l}\text { MRCP: intrahepatic } \\
\text { beading of bile ducts } \\
\text { No biliary hypertrophy or } \\
\text { dilation }\end{array}$ & Prednisone & Partially resolved \\
\hline Yosikawa (2021) & $75 \mathrm{M}$ & $\begin{array}{l}\text { NSCLC (squamous } \\
\text { cell carcinoma) }\end{array}$ & Abnormal LFTs & $\begin{array}{l}\text { MRCP: diffuse dilatation } \\
\text { of the common bile duct } \\
\text { and multifocal stenosis } \\
\text { pre-stenotic dilatation } \\
\text { from the perihilar to } \\
\text { intrahepatic bile duct }\end{array}$ & Prednisone & $\begin{array}{l}\text { No resolution, } \\
\text { patient death }\end{array}$ \\
\hline Talbot (2021) & $69 \mathrm{M}$ & $\begin{array}{l}\text { NSCLC (squamous } \\
\text { cell carcinoma) }\end{array}$ & Abnormal LFTs & $\begin{array}{l}\text { MRCP: irregular } \\
\text { intrahepatic biliary tree } \\
\text { with focal areas of } \\
\text { beading and structuring }\end{array}$ & $\begin{array}{l}\text { Prednisone and } \\
\text { mycophenolate mofetil } \\
\text { then ursodeoxycholic } \\
\text { acid }\end{array}$ & Partially resolved \\
\hline Hirasawa (2021) & $64 \mathrm{M}$ & $\begin{array}{l}\text { NSCLC (squamous } \\
\text { cell carcinoma) }\end{array}$ & $\begin{array}{l}\text { Abdominal pain } \\
\text { and deranged } \\
\text { LFTs }\end{array}$ & $\begin{array}{l}\text { MRCP: beaded } \\
\text { constriction and } \\
\text { dilatation of the } \\
\text { peripheral intrahepatic } \\
\text { bile duct; thickening of } \\
\text { extrahepatic bile duct }\end{array}$ & $\begin{array}{l}\text { Prednisone, } \\
\text { mycophenolate mofetil, } \\
\text { tacrolimus }\end{array}$ & $\begin{array}{l}\text { No resolution, } \\
\text { patient death }\end{array}$ \\
\hline Present case & $75 \mathrm{~F}$ & NSCLC & $\begin{array}{l}\text { Abnormal LFTs, } \\
\text { jaundice }\end{array}$ & $\begin{array}{l}\text { CT and MRCP: no } \\
\text { abnormalities detected }\end{array}$ & $\begin{array}{l}\text { Methylprednisolone and } \\
\text { prednisone }\end{array}$ & $\begin{array}{l}\text { Completely } \\
\text { resolved }\end{array}$ \\
\hline
\end{tabular}

Adapted in part from Onoyama et al. ${ }^{4}$

CT, computed tomography; EUS, endoscopic ultrasound; LFTs, liver function tests; MRCP, magnetic resonance cholangiopancreatography; NSCLC, non-small cell carcinoma.

${ }^{\mathrm{a}}$ First author and year published. 
Conflicts of interest and sources of funding: The authors state that there are no conflicts of interest to disclose.

\section{Andrew Kynaston ${ }^{1}$, Ken Liu ${ }^{2,3}$, Alex Davis ${ }^{4}$, Steven $\mathrm{Kao}^{3,4}$, Catriona McKenzie ${ }^{3,5}$}

${ }^{1}$ Royal Prince Alfred Hospital, Camperdown, NSW, Australia; ${ }^{2} A W$ Morrow Gastroenterology and Liver Centre, Royal Prince Alfred Hospital, Camperdown, NSW, Australia; ${ }^{3}$ Sydney Medical School, The University of Sydney, Camperdown, NSW, Australia; ${ }^{4}$ Department of Medical Oncology, Chris O'Brien Lifehouse, Camperdown, NSW, Australia; ${ }^{5}$ Department of Tissue Oncology and Diagnostic Pathology, New South Wales Health Pathology, Royal Prince Alfred Hospital, Camperdown, NSW, Australia

Contact A/Prof Catriona McKenzie.

E-mail: Catriona.McKenzie@ health.nsw.gov.au

1. Yoneda K, Imanishi N, Ichiki Y, et al. Immune checkpoint inhibitors (ICIs) in non-small cell lung cancer (NSCLC). J UOEH 2018; 40: 173-89.

2. Pardoll DM. The blockade of immune checkpoints in cancer immunotherapy. Nat Rev Cancer 2012; 12: 252-64.

3. Remash D, Prince DS, McKenzie C, Strasser SI, Kao S, Liu K. Immune checkpoint inhibitor-related hepatotoxicity: a review. World J Gastroenterol 2021; 27: 5376-91.

4. Onoyama T, Takeda Y, Yamashita T, et al. Programmed cell death-1 inhibitor-related sclerosing cholangitis: a systematic review. World $J$ Gastroenterol 2020; 26: 353-65.

5. Therapeutic Goods Administration. Australian Public Assessment Report for Nivolumab: January, 2020. Canberra: Australian Government Department of Health, 2020.

6. Gelsomino F, Vitale G, D'Errico A, et al. Nivolumab-induced cholangitic liver disease: a novel form of serious liver injury. Ann Oncol 2017; 28: 671-2.

7. McClure T, Cui W, Asadi K, et al. Case of nivolumab-induced sclerosing cholangitis: lessons from long-term follow-up. BMJ Open Gastroenterol 2020; 7: e000487.

8. Yoshikawa Y, Imamura M, Yamaoka K, et al. A case with lifethreatening secondary sclerosing cholangitis caused by nivolumab. J Clin Gastroenterol 2021; 14: 283-7.

9. Talbot S, MacLaren V, Lafferty H. Sclerosing cholangitis in a patient treated with nivolumab. BMJ Case Rep 2021; 14: e241700.

10. Hirasawa Y, Yoshimura K, Matsui H, et al. A case report on severe nivolumab-induced adverse events similar to primary sclerosing chol angitis refractory to immunosuppressive therapy. J Med 2021; 100: e25774.

11. Imoto K, Kohjima M, Hioki T, et al. Clinical features of liver injury induced by immune checkpoint inhibitors in Japanese patients. Can Gastroenterol Hepatol 2019; 2019: 6391712.

12. Kawakami H, Tanizaki J, Tanaka K, et al. Imaging and clinicopathological features of nivolumab-related cholangitis in patients with nonsmall cell lung cancer. Invest New Drugs 2017; 35: 529-36.

DOI: https://doi.org/10.1016/j.pathol.2021.11.009

\section{Primary high grade serous carcinoma of the appendix: a diagnostic dilemma}

To the Editor,

High grade serous carcinoma (HGSC) constitutes the major subtype of surface epithelial gynaecological cancer. The ovaries/fallopian tubes are the usual likely primary organs; however, the uterus, cervix, and peritoneum have also been reported as other primary sites. Rarely, it has been reported in extraperitoneal locations such as retroperitoneum, broad ligament, endocervix, and pelvic and retroperitoneal lymph nodes. The 2019 World Health Organization (WHO) classification of digestive system tumours does not list Müllerian type serous carcinoma as an entity in the digestive system. It does discuss a malignant transformation in a pancreatic cystadenoma (serous cystadenocarcinoma), ${ }^{1}$ which has morphology and immunophenotype quite unlike the Müllerian type serous carcinoma, which is one of the most common tumours of the female genital tract. ${ }^{2,3}$

Exhaustive literature search by various keyword combinations via Google Scholar and PubMed failed to produce a single case report of any primary gastrointestinal serous carcinoma of the Müllerian type. Even case reports of nongastrointestinal serous carcinoma mimicking a gastrointestinal primary are a rarity. One report described a peritoneal primary ${ }^{4}$ and another was a metastasis from a microscopic primary in the fimbria.

We report a patient presenting with HGSC involving solely the lower gastrointestinal tract without a trace of a primary elsewhere and with no history of chemotherapy before her debulking surgery.

A middle-aged female presented at an outside medical centre with pain in the abdomen which was clinically diagnosed as appendicitis. Laparoscopic appendicectomy was done which was reported as a Grade 3 neuroendocrine tumour in a peripheral laboratory without immunohistochemistry. The histopathology report of the appendix was reviewed at our centre and it was reported as a HGSC. The tumour appeared as a whitish irregular growth involving the wall of the appendix with base involved; the proper anatomy of the specimen was not ascertained as per the outside report. Lymphovascular invasion was seen. Immunohistochemistry (IHC) was strongly positive for PAX-8 and WT1; p16 showed block-like positivity; synaptophysin was negative; and p53 was strongly and diffusely positive (mutated phenotype) (Fig. 1). The immunophenotype suggested an ovarian/tubal/peritoneal primary, therefore gynaecological consultation was recommended.

Her serum CA-125 was subsequently found to be elevated at $191.0 \mathrm{U} / \mathrm{mL}$ while CEA was normal $(3.62 \mathrm{ng} / \mathrm{mL})$. Positron emission tomography-computed tomography scan, done outside and reviewed in-house, showed that there was no peritoneal disease but there was significant nodal disease along the retro peritoneum and pelvis. The disease appeared to be resectable and the patient was taken up for primary debulking surgery.

Intraoperatively, there was a large tumour of size $10 \mathrm{~cm}$ at the mesentery near the ileo-caecal junction, which was suspicious for an enlarged lymph nodal mass. The base of the appendix was also indurated. The rest of the small bowel and mesentery were free from disease. The porta hepatis and root of mesentery were palpated and were found to be free from infiltrative disease. The large bowel was free from gross disease. All quadrants of the abdomen (as per Sugarbaker's PCI score) were assessed and the disease was deemed resectable to less than $1 \mathrm{~cm}$ residual disease. Incision was extended and cytoreductive procedures started. The patient underwent total omentectomy, hysterectomy with bilateral salpingo-oophorectomy, right hemicolectomy and ileo-colic anastomosis, removal of parietal peritoneum deposit, and peritoneal lavage.

Surgical specimens were processed and examined in house. The uterus, cervix, and bilateral adnexal were free of 